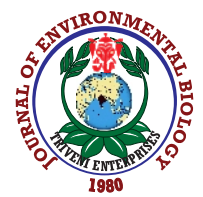

\title{
Effect of light sources and intensities on the growth of propagated corals Dipsastraea pallida (Dana, 1846) and Dipsastraea speciosa (Dana, 1846)
}

\author{
S.M. Lim ${ }^{1}$, N.L.W.S. Wong ${ }^{2 *}$ and A. Arshad ${ }^{2,3}$ \\ ${ }^{1}$ Institute of Bioscience, Universiti Putra Malaysia, Serdang, 43400, Selangor, Malaysia, \\ ${ }^{2}$ International Institute of Aquaculture and Aquatic Science, Universiti Putra Malaysia, Port Dickson, 71050, Negeri Sembilan, Malaysia \\ ${ }^{3}$ Department of Aquaculture, Faculty of Agriculture, Universiti Putra Malaysia, Serdang, 43400, Selangor, Malaysia. \\ *Corresponding Author Email : nurleena@upm.edu.my
}

\section{Abstract}

Aim: To determine the effect of different light sources and intensities on the growth of propagated scleractinian corals Dipsastraea pallida and Dipsastraea speciosa from Tanjung Tuan, Melaka.

Methodology: A total of 120 replicates from each D. pallida and D. speciosa were kept under LED and fluorescent lights with three controlled intensities (Photosynthetic Photon Flux Density, PPFD = 60, 80 and 100 $\mu \mathrm{mol} \mathrm{m} \mathrm{m}^{-1} \mathrm{~s}^{-1}$. Initial weight was recorded before the experiment and weekly growth in weights was recorded for six weeks.

Results: Dipsastraea pallida and D. speciosa achieved 8.26 $\mathrm{mg}$ and $8.28 \mathrm{mg}$ under LED light, and $8.16 \mathrm{mg}$ and $8.22 \mathrm{mg}$ growth under fluorescent light in six weeks $60 \mu \mathrm{mol} \mathrm{m}^{-2} \mathrm{~s}^{-1}$. The highest specific growth rate for $D$. pallida and $D$. speciose was observed at $60 \mu \mathrm{mol} \mathrm{m} \mathrm{m}^{-2} \mathrm{~s}^{-1}$. Insignificant difference was observed between LED and fluorescent lights for coral growth with same intensity exposure. The study indicates that moderate light intensity at $60 \mu \mathrm{mol} \mathrm{m} \mathrm{m}^{-2} \mathrm{~s}^{-1}$ enhanced better growth rate than higher intensity for $D$. pallida and $D$. speciosa from the turbid waters of Tanjung Tuan, Melaka.

Interpretation: The experiment showed that corals from turbid water, $D$. pallida and $D$. speciosa grow better under moderate intensities than high intensities under both LED and fluorescent lights. However, intensity from fluorescent light was less penetrating in seawater as the lights have to be closer to water surface than LED lights which leads to the concern of allowing of excess heat into the culture medium.

Key words: Corals, Dipsastraea pallida, Dipsastraea speciosa, Fluorescent, Light intensity, Scleractinian coral

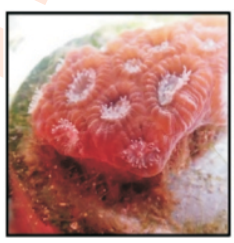

Dipsastreaea pallida
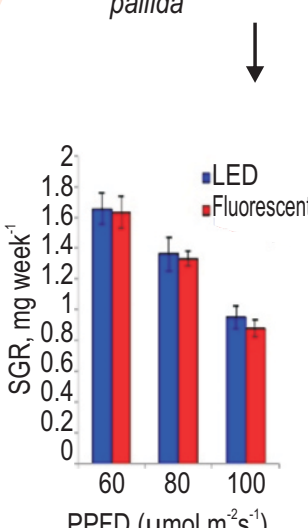

$\operatorname{PPFD}\left(\mu \mathrm{mol} \mathrm{m}^{-2} \mathrm{~s}^{-1}\right)$
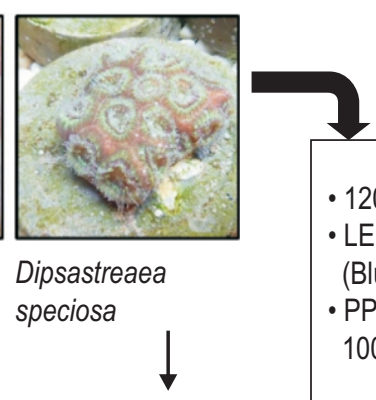

- 120 replicates each

- LED and Fluoresecnt

(Blue and White)

- PPFD 60, 80 and

$100 \mu \mathrm{mol} \mathrm{m} \mathrm{s}^{-1}$

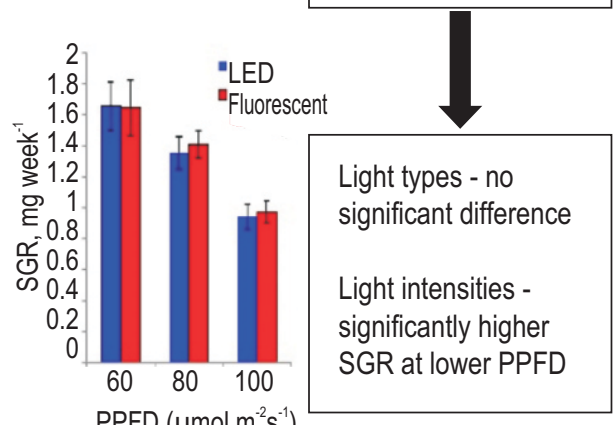

How to cite : Lim, S.M., N.L.W.S. Wong and A. Arshad: Effect of light sources and intensities on the growth of propagated corals Dipsastraea pallida (Dana, 1846) and Dipsastraea speciosa (Dana, 1846). J. Environ. Biol., 41, 1186-1193 (2020). 


\section{Introduction}

Coral reefs with tremendous ecological and economic importance are reported to decline gradually due to poaching activities and natural forces since 1970s (Hii et al., 2009). It has been predicted that over million of these species may face extinction in the coming decades (Bruno and Selig, 2007). Lighting is essential for the growth of most scleractinian corals by the process of light-enhanced calcification through zooxanthellae (Tentori and Allemand, 2006). Coral aquaculture is gaining importance as one of the solutions offered for reef rehabilitation and to reduce poaching for marine ornamental trade. In order to conduct economically viable coral culture, it is essential to develop optimized culture protocol. Corals in Tanjung Tuan waters, Malacca Strait have been threatened by poaching and environmental stresses for years (Lee et al., 2004). In 1988, Tanjung Tuan was gazetted as Fisheries Protected Area to conserve and protect corals from poachers. Tanjung Tuan, also known as Cape Rachado, with small fringing reef, is one of the four sites (including Langkawi Island, Payar Island and Pangkor Island) in the west coast of Peninsular Malaysia which has significant coral reefs (Lim, 2015). Corals in Tanjung Tuan waters have been degraded over the years as a result of increasingly turbid water due to coastal developments. Flat topography in Tanjung Tuan intertidal reefs and their exposure during low tide have possibly increased the amount of suspended sediments on the corals during changes of tides (Philipp and Fabricius, 2003). High sedimentation rate with accumulation rate as high as 76.83 $\mathrm{mg} \mathrm{cm}^{-2}$ day $^{-1}$ was recorded in 2004 at Tanjung Tuan reefs (Lee et al., 2004), and coral cover percentage in this area has been decreasing from $32.9 \%$ in early 1980's (Goh and Sasekumar, 1981) to $14.3 \%$ (Lee et al., 2004) after approximately 30 years. Suspended sediment reduces light intensity received by the corals, and it was speculated that corals prefer clearer water as some experiments have shown the growth rates of coral increase with increasing intensity (Fitzgerald, 2010; Schutter et al., 2011; Rodolfo-Metalpa et al., 2007). In this study, it is hypothesized that corals from turbid waters at Tanjung Tuan will respond similarly like clear water corals which will lead to increase in growth rate with increasing light intensities.

\section{Materials and Methods}

Specimen collection and propagation : Two scleractinian coral species, $D$. pallida and $D$. speciosa from Tanjung Tuan intertidal reef were selected for the study. Fragments from the colonies of these two species were collected at $02^{\circ} 24^{\prime} 53.6^{\prime \prime} \mathrm{N}, 101^{\circ} 51^{\prime} 16.8^{\prime \prime} \mathrm{E}$ with permission from the Department of Fisheries, Malaysia. Samples were collected during low tide when parent colonies were accessible by foot, exposed to air with water level less than $0.1 \mathrm{~m}$ in depth. Parts of the parent colonies were knocked off using hammer and chisel. Samples were brought back to the laboratory in International Institute of Aquaculture and Aquatic
Sciences (I-AQUAS), UPM (formerly known as Marine Science Centre, COMAS), Port Dickson, Negeri Sembilan. After $24 \mathrm{hr}$ conditioning period in a holding tank, coral fragments were then propagated by microfragmenting method (Forsman et al., 2015; Forsman et al., 2006) using Gryphon Diamond Band Saw Model C-40 into 120 pieces for each species. Coral fragments of approximately $1 \mathrm{~cm}$ diameter were glued onto cement blocks. Propagated fragments that originated from the same parent colonies were used as they were of the same genotype. It was hypothesized that they will provide similar responses with the same treatment. After propagation, all fragments were put into transition tank with recirculating filter system and weekly $50 \%$ water change was performed during the experimental period of 7 weeks (Wijgerde et al., 2013).

In-situ water parameters : In-situ water parameters of light intensity was recorded hourly where the parent colonies were collected using Onset Hobo Data Logger Set for one month tide cycles. Data collected was then converted into Photosynthetic Photon Flux Density, PPFD, calibrated using LI-COR LI-250A light meter with LI-192 Underwater Quantum Sensor. In-situ light intensity data was used to estimate suitable light intensity for coral growth in the experiment.

Experimental design : In order to determine the effects of light sources and intensities on coral growth, coral specimens were subjected to two light sources, LED (Marine Glo Actinic Blue Marine Aquarium Bulb) and fluorescent (Aqua Zonic T5 HO, Actinic blue and sun tubes) with three controlled intensities (60 $\mu \mathrm{mol} \mathrm{m} \mathrm{m}^{-2}, 80 \mu \mathrm{mol} \mathrm{m} \mathrm{m}^{-1}$ and $\left.100 \mu \mathrm{mol} \mathrm{m} \mathrm{m}^{-2}\right)$. Due to different light penetration of LED and fluorescent, samples were arranged at different depths to achieve specific light levels needed for the experiments, and coral fragments on the same panel were subjected to similar intensity. Panels were placed at a specific water depth adjusted by using LI-COR LI-250A light meter with LI192 Underwater Quantum Sensor, and intensity at every coral fragment position was recorded (Fitzgerald, 2010). The depth of the panels from water surface were approximately $10 \mathrm{~cm}$ (100 umol m $\left.\mathrm{m}^{-2} \mathrm{~s}^{-1}\right), 12.5 \mathrm{~cm}\left(80 \mu \mathrm{mol} \mathrm{m} \mathrm{s}^{-1}\right), 13 \mathrm{~cm}\left(60 \mu \mathrm{mol} \mathrm{m} \mathrm{s}^{-1}\right)$ for the experiment using LED lights, and $22 \mathrm{~cm}\left(100 \mu \mathrm{mol} \mathrm{m} \mathrm{m}^{-2} \mathrm{~s}^{-1}\right), 29$ $\mathrm{cm}\left(80 \mu \mathrm{mol} \mathrm{m} \mathrm{s}^{-1}\right)$ and $35 \mathrm{~cm}\left(60 \mu \mathrm{mol} \mathrm{m} \mathrm{m}^{-2}\right)$ using fluorescent lights. Light intensities were kept constant to determine the growth rate of corals throughout the experiment. Diagrams of the experimental design and coral fragments arrangement are shown in Fig. 1. LED and fluorescent lights experimental aquaria were identical with seawater volume approximately $100 \mathrm{~L}$ and flow rate at $450 \mathrm{ml} \mathrm{s}^{-1}$, connected to a recirculating filter system. Weekly $50 \%$ water change ( $5 \mu \mathrm{m}$ filtered seawater at $31 \mathrm{ppt}$ ) was carried out throughout the experimental period. Twenty samples from each species were randomly placed on each panel and were randomly shuffled weekly. Specific intensities were created using fluorescent bulbs ( $4 \times 39 \mathrm{~W}$ ) and two LED light panels ( $36 \mathrm{~W}$ and $24 \mathrm{~W})$. Blue and white wavelengths were prioritized in this study 
(a)

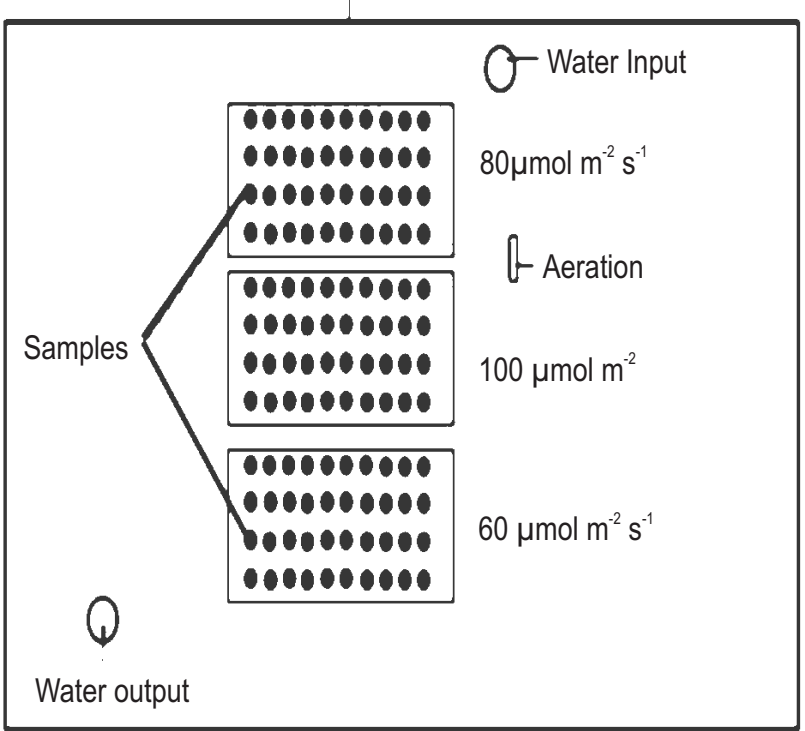

(b)

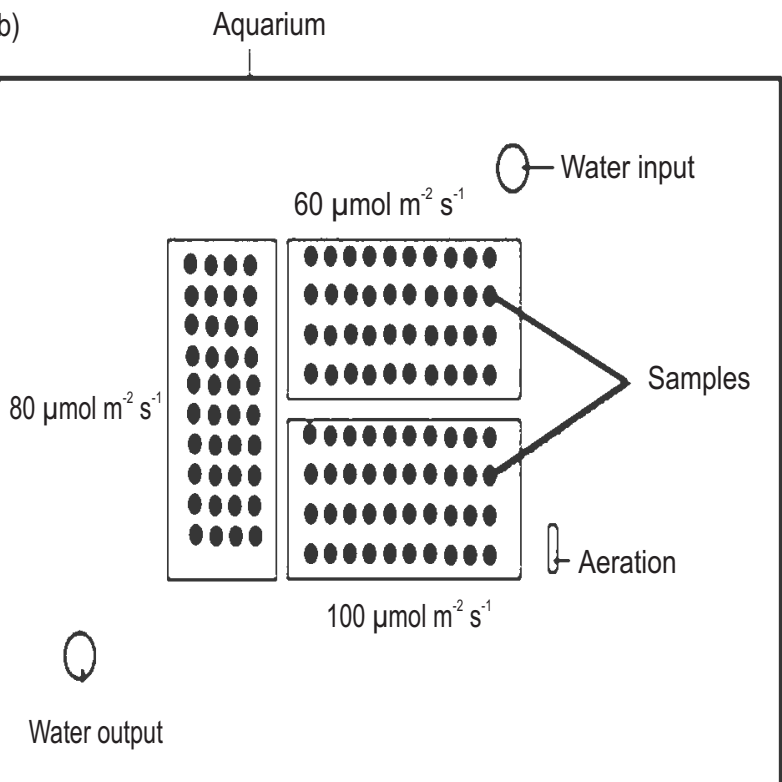

Fig. 1 : Diagram of experimental design with three different light intensities under LED (a) and fluorescent light sources and (b) for both $D$. pallida and $D$. speciosa at 60,80 and $100 \mu \mathrm{mol} \mathrm{m}^{-2} \mathrm{~s}^{-1}$.

as it has been proven that corals exhibit better growth rate and lower mortality using these lights (Fitzgerald, 2010; Wijgerde et al., 2013; Karpenko and Ganapetyan, 2007). Each light source was turned on from 07:00 to 19:00 hrs aided with a timer. Coral growth was measured weekly in milligram using calibrated buoyance electronic balance (TE 1502S) for six continuous weeks. Temperature of seawater was recorded with a digital thermometer and maintained between $26.7-31.0^{\circ} \mathrm{C}$ (ambient room temperature during the day and submerged heaters were used at night). Water parameters like ammonia, nitrite, nitrate, phosphate, calcium, $\mathrm{pH}$ and magnesium were monitored weekly using Hach DR2800 to ensure that they were within the desired range (Table 1). Water was changed if water parameters were out of desired range. Three cement blocks without coral fragments were put into each LED and fluorescent lights experimental aquaria respectively as control and for data calibration to obtain growth rate in growth per coral fragment per week $\left(\mathrm{mg} \mathrm{week}^{-1}\right)$. No

Table 1: Controlled ranges of water parameters during the experiments

\begin{tabular}{ll}
\hline Parameters & Range \\
\hline Ammonia & $0.00-0.25 \mathrm{mgl}^{-1}$ \\
Nitrite & $0.00-0.025 \mathrm{mgl}^{-1}$ \\
Nitrate & $0.00-5.00 \mathrm{mgl}^{-1}$ \\
Phosphate & $0.00-0.025 \mathrm{mgl}^{-1}$ \\
Calcium & $460-500 \mathrm{ppm}$ \\
$\mathrm{pH}$ & $7.2-7.6$ \\
Magnesium & $1410-1500 \mathrm{ppm}$ \\
Salinity & $33-34 \mathrm{ppt}$ \\
Temperature & $26.7-31.0^{\circ} \mathrm{C}$ \\
\hline
\end{tabular}

additional of food was supplied to corals throughout the experiment.

In-situ light intensities regime : Data collected using Onset Hobo Data Logger Set was converted into Photosynthetic Photon Flux Density, PPFD, calibrated using LI-COR LI-250A light meter with LI-192 Underwater Quantum Sensor. In-situ light intensity data was used to estimate suitable light intensity for coral growth in the experiment. The following equation was used to convert lux of sunlight into Photosynthetic Photon Flux Density, PPFD ( $\mu \mathrm{mol})$. The following equation was used to convert lux of sunlight into Photosynthetic Photon Flux Density (Thimijan and Heins, 1982)

$$
\text { PPFD }=1 \text { lux } \times 0.0185=0.0185 \mu \mathrm{mol}
$$

Growth rate : Weekly specific growth rate (SGR) was calculated by the formula given below (Fitzgerald, 2010)

$$
\operatorname{SGR}\left(\text { week }^{-1}\right)=\frac{(\mathrm{Wt}-\operatorname{InWt}-1)}{\Delta \mathrm{t}}
$$

where, $\mathrm{Wt}$ is the final weight of corals; $\mathrm{Wt}-1$ is the Initial weight of corals; $\Delta t$ is the growth interval in week. Specific growth rate was expressed in mg week ${ }^{-1}$.

Statistical analyses : Data were analysed using IBM SPSS Statistics 21. Shapiro - Wilk test was used to study the normality of data (Zar, 2010). Significance level of effects of light types (LED and fluorescent) and light intensities on the growth of $D$. pallida and $D$. speciosa, and the strength of correlations were analysed 
using Two-way ANOVAand Pearson's correlation (Zar, 2010).

\section{Results and Discussion}

In-situ light intensity and seawater temperature data are shown in Fig. 2. The highest light intensities were recorded during low spring tide (day 4, 5, and 29) with PPFD above $1000 \mu \mathrm{mol} \mathrm{m}$ $\mathrm{s}^{-1}$ (Fig. 2a) and temperature above $37^{\circ} \mathrm{C}$ (Fig. 2b). However, average light intensity during daylight hours (12 hr) was 60.30 $\mu \mathrm{mol} \mathrm{m} \mathrm{m}^{-2}$, while the readings above $1000 \mu \mathrm{mol} \mathrm{m} \mathrm{s}^{-1}$ were disregarded as these readings may be recorded during low tide aerial exposure for a short period of time (Fig. 2a). Thus, experimental light intensities were set at 60,80 and $100 \mu \mathrm{mol} \mathrm{m}^{-2}$ $\mathrm{s}^{-1}$ between average light intensity and within the range of intensity which shallow reefs received in most days. In-situ temperature data was recorded during the El-Niño event in 2016, where sea water temperatures reached thermal fluctuation up to $42.28^{\circ} \mathrm{C}$, with the average $30.82^{\circ} \mathrm{C}$.

Significant differences were observed in the mean growth of $D$. pallida and $D$. speciosa fragments after exposure to different light intensities for six weeks. The mean growth for both $D$. pallida and $D$. speciosa was significantly higher at $60 \mu \mathrm{mol} \mathrm{m} \mathrm{m}^{-2}$ under both LED and fluorescent lights, while there were no significant differences in the mean growth between species when exposed to same light source and intensities. Significant lower mean growths were recorded at higher light intensities for both coral species (Table 2) and no significant difference in results were observed under LED and fluorescent lights with same light intensities.

Coral fragments of both Dipsastraea species exposed to $60 \mu \mathrm{mol} \mathrm{m} \mathrm{m}^{-2}$ showed the highest specific growth rate, compared to higher light intensities, however specific growth rate between different light sources was not significantly different (Fig. 3). At 60 $\mu \mathrm{mol} \mathrm{m} \mathrm{m}^{-1}$ LED light intensity, the specific growth rate of $D$. pallida was relatively $\left(1.66 \pm 0.15 \mathrm{mg}^{-1}\right.$ week $\left.^{-1}\right)$, followed by $80 \mu \mathrm{mol}$ $\mathrm{m}^{-2} \mathrm{~s}^{-1}\left(1.36 \pm 0.12 \mathrm{mg}\right.$ week $\left.^{-1}\right)$ and $100 \mu \mathrm{mol} \mathrm{m}^{-2} \mathrm{~s}^{-1}(0.95 \pm 0.09 \mathrm{mg}$ week $^{-1}$ ) light intensities, respectively (Fig. 3a). Specific growth rate of $D$. pallida showed similar results when exposed to fluorescent lights at same intensities. The highest specific growth rate $1.65 \pm 0.08 \mathrm{mg}$ week ${ }^{-1}$ was reported at $60 \mu \mathrm{mol} \mathrm{m}^{-2} \mathrm{~s}^{-1}$ intensity followed by $1.33 \pm 0.06 \mathrm{mg}$ week $^{-1}$ at $80 \mu \mathrm{mol} \mathrm{m} \mathrm{m}^{-2} \mathrm{~s}^{-1}$, while the lowest specific growth rate $0.88 \pm 0.07 \mathrm{mg}$ week $^{-1}$ was observed at $100 \mu \mathrm{mol} \mathrm{m} \mathrm{m}^{-1} \mathrm{~s}^{-1}$ light intensity (Fig. 3a). Specific growth rate of $D$. speciosa also showed similar results when exposed to LED lights at same intensities, where the highest specific growth rate $1.65 \pm 0.16 \mathrm{mg}$ week $^{-1}$ was reported at $60 \mu \mathrm{mol} \mathrm{m}^{-2} \mathrm{~s}^{-1}$ light intensity followed by $80 \mu \mathrm{mol} \mathrm{m}^{-2} \mathrm{~s}^{-1}\left(1.35 \pm 0.12 \mathrm{mg}\right.$ week $\left.^{-1}\right) \mathrm{mg} \mathrm{week}^{-1}$ and $100 \mu \mathrm{mol} \mathrm{m} \mathrm{s}^{-1}\left(0.94 \pm 0.09 \mathrm{mg}^{-1}\right.$ week $\left.^{-1}\right)$, respectively (Fig. 3b). Dipsastraea speciosa showed the highest specific growth rate at $60 \mu \mathrm{mol} \mathrm{m} \mathrm{s}^{-1}$ under fluorescent $\left(1.63 \pm 0.16 \mathrm{mg}\right.$ week $\left.^{-1}\right)$ followed by $80 \mu \mathrm{mol} \mathrm{m} \mathrm{s}^{-1}\left(1.41 \pm 0.01 \mathrm{mg}^{-1}\right.$ week $\left.^{-1}\right)$ and at $100 \mu \mathrm{mol} \mathrm{m} \mathrm{s}^{-1}$ $\left(0.97 \pm 0.08\right.$ mg week $\left.^{-1}\right)$ respectively (Fig. 3b).

A Shapiro-Wilk's test $(p>0.5)$ (Zar, 2010) and visual inspection of their histogram, normal $Q-Q$ plots showed that the Specific Growth Rate was normally distributed for both species.
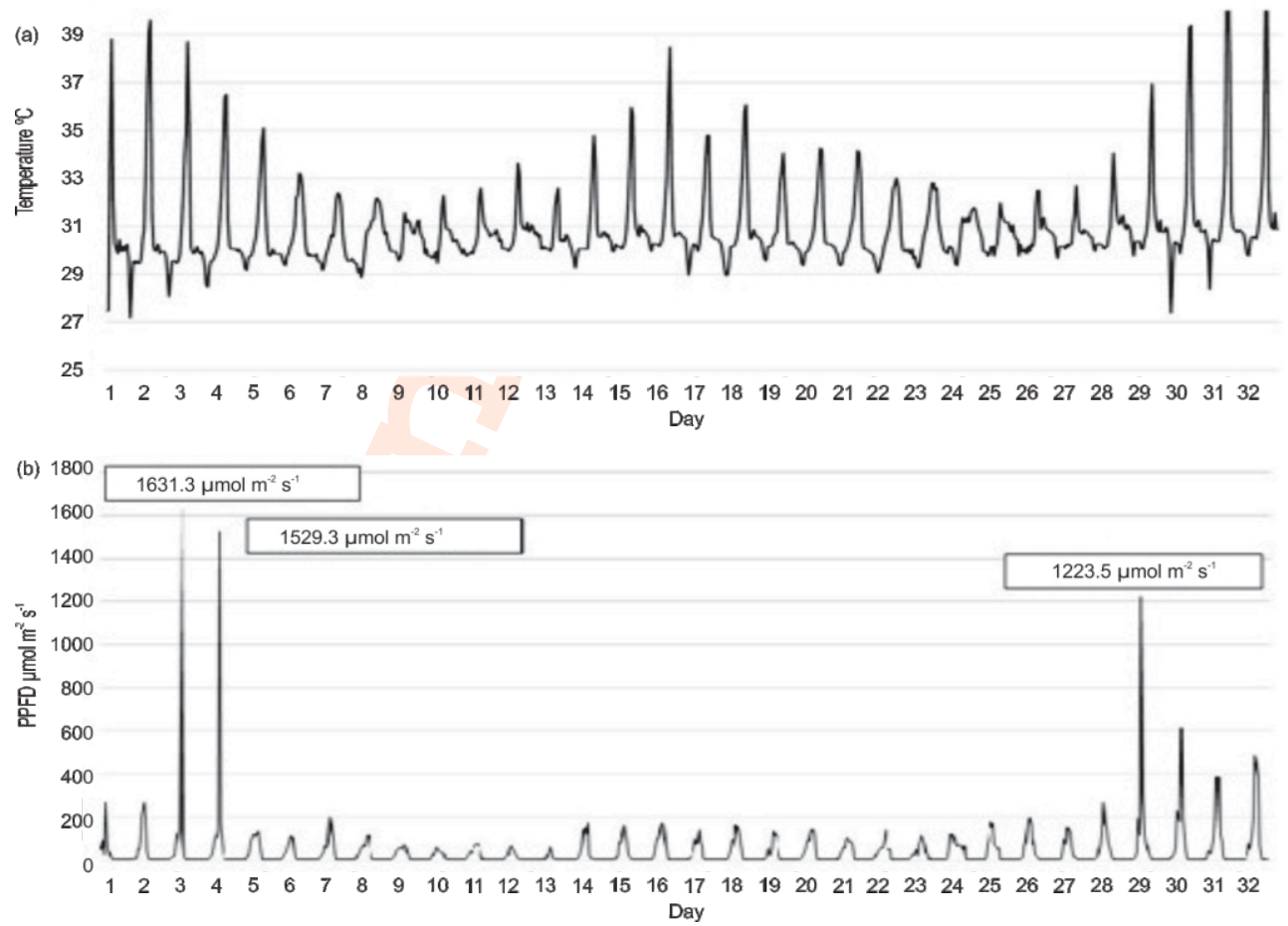

Fig. 2 : In-situ PAR measured in photosynthetic photon flux density (A) and seawater temperature (B) at Tanjung Tuan shallow reefs area for 32 days. 
Table 2 : Comparison of light types (LED and fluorescent) and Photosynthetic Photon Flux Density (PPFD) on the mean growth of $D$. pallida and $D$. speciosa samples for a period of six weeks.

\begin{tabular}{|c|c|c|c|}
\hline \multirow[t]{2}{*}{ Light Type } & \multirow[t]{2}{*}{$\operatorname{PPFD}\left(\mu \mathrm{mol} \mathrm{m} \mathrm{s}^{-1}\right)$} & \multicolumn{2}{|c|}{$\begin{array}{l}\text { Mean } \pm \text { S.D. }(\mathrm{mg}) \\
\operatorname{Min}-\operatorname{Max}(\mathrm{n})\end{array}$} \\
\hline & & D. pallida & D. speciosa \\
\hline \multirow[t]{3}{*}{ LED } & 60 & $\begin{array}{l}8.26 \pm 0.76^{a} \\
7.99-8.57(20)\end{array}$ & $\begin{array}{l}8.28 \pm 0.57^{\mathrm{a}} \\
8.03-8.53(20)\end{array}$ \\
\hline & 80 & $\begin{array}{l}6.81 \pm 0.40^{b} \\
6.51-7.10(20)\end{array}$ & $\begin{array}{l}6.77 \pm 0.56^{\mathrm{b}} \\
6.52-7.02(20)\end{array}$ \\
\hline & 100 & $\begin{array}{l}4.74 \pm 0.49^{c} \\
4.45-5.04(20)\end{array}$ & $\begin{array}{l}4.42 \pm 0.49^{\circ} \\
4.42-4.92(20)\end{array}$ \\
\hline \multirow[t]{3}{*}{ FLUORESCENT } & 60 & $\begin{array}{l}8.16 \pm 0.76^{a} \\
7.87-8.46(20)\end{array}$ & $\begin{array}{l}8.22 \pm 0.67^{\mathrm{a}} \\
7.97-8.47(20)\end{array}$ \\
\hline & 80 & $\begin{array}{l}6.66 \pm 0.92^{b} \\
6.37-6.96(20)\end{array}$ & $\begin{array}{l}7.05 \pm 0.60^{b} \\
6.80-7.30(20)\end{array}$ \\
\hline & 100 & $\begin{array}{l}4.40 \pm 0.52^{\circ} \\
4.10-4.68(20)\end{array}$ & $\begin{array}{l}4.86 \pm 0.49^{\circ} \\
4.61-5.11(20)\end{array}$ \\
\hline
\end{tabular}

Mean within rows with the same alphabet are not significantly different (Two- way ANOVA, Tukey). (Same alphabet in a column indicates no significant difference, Two-way ANOVA. Significantlevel: $a>b>c$ ).

Assumption of homogeneity of variances was tested for all groups using Two-way ANOVA and this showed homogeneity of variance $(p>0.05)$. Pearson correlation between SGR and light intensities indicated strong negative correlations, showed a correlation of $r>$ -0.90 between Dipsastraea spp. and various light intensities with either LED or fluorescent lights. The corals exhibited better growth rate with decreasing light intensity. Correlations were significant at 0.01 levels.

The mean growth rate of $D$. pallida and $D$. speciosa under different intensities of LED and fluorescent lights over six weeks are shown in Fig. 4. The growth rate of Dipsastraea pallida and D. speciosa differed under different light sources and intensities, as there were variations in weight increment rate for coral fragments exposed to different light treatments. The growth rate of $D$. pallida (Fig. 4a) exposed to LED lights appeared relatively stable for all light intensities, with slightly decreased for the first 3 weeks but increased at week-4. D. pallida coral fragments exposed to fluorescent lights (Fig. 4b) showed similar under $60 \mu \mathrm{mol} \mathrm{m} \mathrm{m}^{-2}$ and $100 \mu \mathrm{mol} \mathrm{m}^{-2} \mathrm{~s}^{-1}$ though at different growth rate. However, at $80 \mu \mathrm{mol} \mathrm{m} \mathrm{s}^{-1}$ under fluorescent lights, growth rate increased and decreased at irregular rate with the highest growth rate at week-4. Despite all that, D. pallida showed better growth trend with lower light intensity for both LED and fluorescent lights.

Dipsastraea speciosa had stable growth trend under LED lights, at 80 and $100 \mu \mathrm{mol} \mathrm{m}^{-2} \mathrm{~s}^{-1}$, except for intensity at $60 \mu \mathrm{mol} \mathrm{m}{ }^{-2}$ $\mathrm{s}^{-1}$ with a sudden decrease in growth at week 3 (Fig. 4c). Nevertheless, the overall growth rate at $60 \mu \mathrm{mol} \mathrm{m} \mathrm{s}^{-1}$ remains higher than other light intensities. While $D$. speciosa recorded similar growth rate under different fluorescent intensities, the
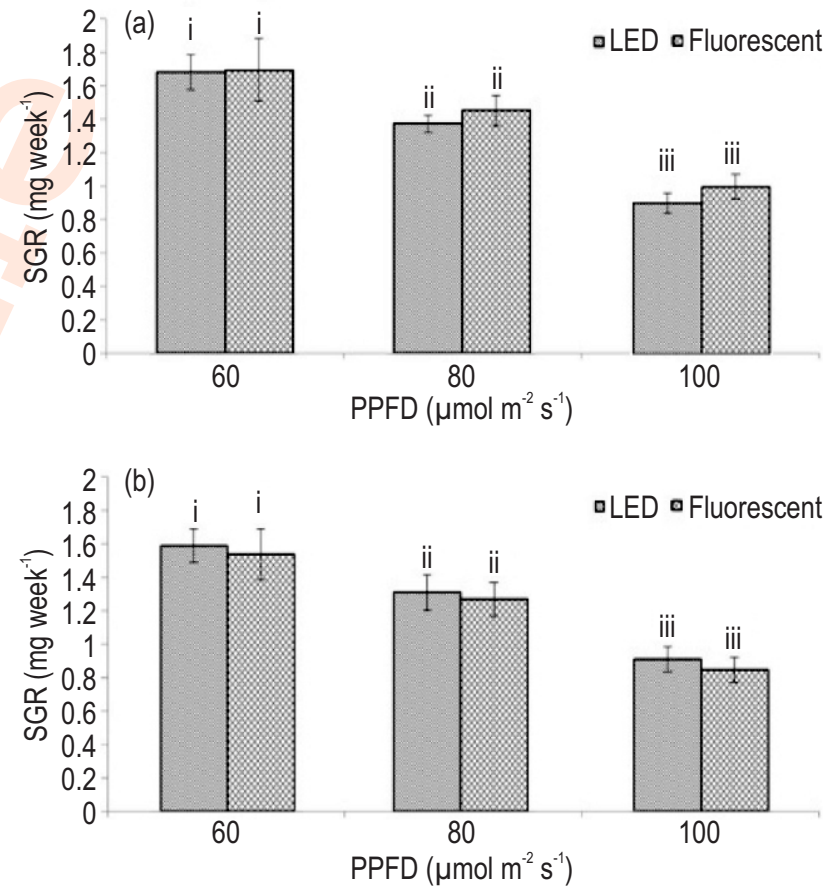

Fig. 3 : Specific growth rate (SGR) (mg week-1) of $D$. pallida (a) and $D$. speciosa (b) under LED and fluorescent lights with different intensities. (Same alphabet indicates no significant difference, two way ANOVA. Significantlevel: $i>$ ii $>$ iii).

growth rate increased at $60 \mu \mathrm{mol} \mathrm{m} \mathrm{m}^{-1}$ and decreased at 100 $\mu \mathrm{mol} \mathrm{m} \mathrm{m}^{-1}$ by week-2 (Fig. 4d). Overall, the growth rates showed relatively more stable trend under LED lights (Fig. 4a, c) 
compared to growth rates under fluorescent lights (Fig. 4b, d) with differentintensities.

All propagated corals appeared healthy throughout the experiment based on colour observation and the survival of propagated corals were $100 \%$ at the end of the experiment. Blue and white lights were selected for both LED and fluorescent lights as red light may cause necrosis of the corals. Blue light has been tested to have significant higher density of zooxanthellae than red light and a higher density of zooxanthellae increases the growth rate (Wijgerde et al., 2013).

LED light source has deeper penetration of photosynthetically active radiation than fluorescent light, where usually corals can achieve higher growth rate with the increasing intensity under LED than fluorescent light source (Fitzgerald, 2010). Results were expected to have higher mean growth with the increasing intensity as faster growth is normally induced by higher intensity with higher photosynthetic rate (Finelli et al., 2006; Finelli et al., 2007). However, the growth of both species had negative correlation with the increase in intensity, with higher growth rate under relatively lower intensities. No significant difference was observed between different light sources under same light intensities in this study. Both light sources enhanced similar growth rate under same intensities.

In this study, faster growth was achieved under lower tested intensity regardless of light sources. Similar results were reported in different coral species such as Galaxea facicularis (Wijgerde et al., 2013), Montipora capricornis (Fitzgerald, 2010), Favia speciosa (Tamir et al., 2008) and Sarcophyton cf. glaucum (Rocha et al., 2013) where propagated corals showed higher growth when exposed to relatively lower light intensities. Higher growth rate of Galaxea fascicularis was recorded with 0.031 day at LED $40-60 \mu \mathrm{mol} \mathrm{m} \mathrm{m}^{-2}$ than at $275-325 \mu \mathrm{mol} \mathrm{m}^{-2} \mathrm{~s}^{-1}$ which was 0.022 day $^{-1}$ (Wijgerde et al., 2013). The lowest growth rate of
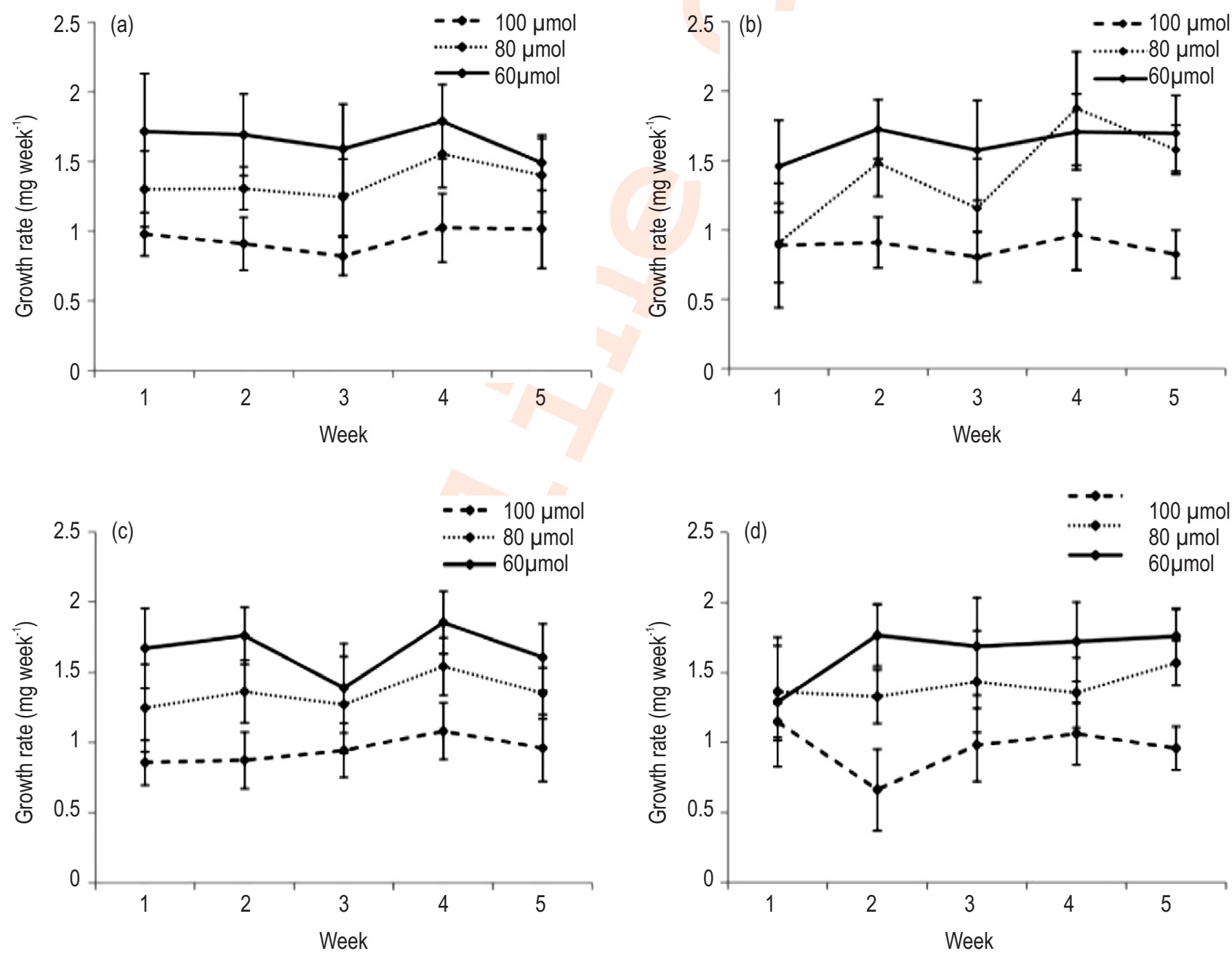

Fig. 4 : Growth rate of $D$. pallida under LED (a) and fluorescent (b) lights, and growth rate of $D$. speciosa under LED (c) and fluorescent (d) lights with different intensities. 
Montipora capricornis was experienced on the top level of metal halide tank in the range of $316-200 \mu \mathrm{mol} \mathrm{s}^{-1} \mathrm{~m}^{2}$ with $\mathrm{H}^{\prime \prime} 0.002$ day $\mathrm{g}^{-1}$. The fragments of Sarcophyton cf. glaucum presented significantly higher values of zooxanthellae density when compared with corals under higher PAR values (Rocha et al., 2013). Though higher light intensity may promote higher photosynthetic rate, it could induce photoinhibition.

The intertidal turbid water corals, $D$. pallida and $D$. speciosa used in this study are less studied as compared to clear water corals. These corals are subjected to higher water temperature and might be exposed to air during low tide. During high tides, they are exposed to low light intensity due to high suspended sediments in the water ranging from $59.61 \mathrm{mg} \mathrm{cm}^{-2}$ day $^{-1}$ to $220.61 \mathrm{mg} \mathrm{cm}^{-2}$ day ${ }^{-1}$ (Lee et al., 2004). Though these species may be exposed to high light intensities during low tide as shown in Fig. 2a, light intensities when corals are submerged are highly affected by high turbidity in Tanjung Tuan waters. Prolonged exposure (12hr) daily in relatively high intensities at 80 $\mu \mathrm{mol} \mathrm{m} \mathrm{m}^{-2}$ and $100 \mu \mathrm{mol} \mathrm{m} \mathrm{s}^{-1}$ may place these turbid water coral species under stress and induce photoinhibition, which may affect their growth.

Corals from pristine environment bleach when exposed to prolonged turbidity causing low light penetrations in water (Bessel-Browne et al., 2017). However, it has been reported that corals from tide pools, which regularly experience exposure to air, stagnant water and temperature extremes cope with hot water much better than corals from below the low-tide mark, where conditions are far more moderate. Previous studies have pointed out that coral reefs are adapted to transient increase in turbidity (Rogers, 1979; Anthony and Fabricius, 2000). This shows that highly-variable, extreme temperature environments can boost the resistance of corals. The results of this study suggest that corals from turbid intertidal environment have managed to thrive even under lower light intensity than their growing environments if stable low lights and constant temperature are provided.

Other than lights, symbiotic corals can supplement their nutrition needs through prey capture. Heterotrophic feeding can effectively increase the skeletal growth of the corals (Ferrier et al., 2003). Dipsastraea coral species are able to conduct heterotrophic feeding other than relying on photosynthesis to overcome nutrient deficiency (Ferrier et al., 2003; Van et al., 2011). Other factors such as water flow rate were found to have a direct influence on the growth of corals, especially in controlled artificial environment. It affects physiological processes such as photosynthesis where lower flow rate leads to the accumulation of oxygen within coral tissues and subsequently increases photorespiration and decreases photosynthesis (Schutter et al., 2011). In addition, as zooxanthellae are important for the growth of corals by food provision through photosynthesis, further studies can be conducted to understand the effect of intensity on zooxanthellae density.
In conclusion, fluorescent and LED lights produce similar results in coral growth as long as the intensities are well adjusted to suit their needs. However, it is essential to know the origin of corals intented for propagation as environmental parameters (e.g. light intensity and exposure) at their place of origin would determine the range of controlled parameters needed when cultured ex-situ.

\section{Acknowledgments}

This research was supported by Putra Grant (GPIPM/2014/9434900) from Universiti Putra Malaysia. The authors would like to express gratitude to the staffs in Pusat Ikan Hiasan Teluk Kemang, Department of Fisheries Malaysia for their assistance in acquiring coral collecting permission and knowledge sharing in coral culture system.

\section{References}

Anthony, K.R.N. and K.E. Fabricius: Shifting roles of heterotrophy and autotrophy in coral energetics under varying turbidity. J. Exp. Mar. Biol. Ecol., 252, 221-253 (2000).

Bessell-Browne, P., P.N. Andrew, F. Rebecca, L.C. Peta and J. Ross: Impacts of light limitation on corals and crustose coralline algae. Nature Publishing Group, London, UK (2017).

Bruno, J.F. and E.R. Selig: Regional decline of coral cover in the IndoPacific: Timing, extent and subregional comparisons. PLOS ONE, 2, e711 (2007).

Forsman, Z., B. Rinkevich and C. Hunter: Investigating fragment size for culturing reef-building corals (Porites lobata and Porites compressa) in ex-situ nurseries. Aquaculture, 261, 89-97 (2006).

Forsman, Z.H., C.A. Page, R.J. Toonen and D. Vaughan: Growing coral larger and faster: Micro-colony-fusion as a strategy for accelerating coral cover. PeerJ., 3, e1313 (2015).

Ferrier-Pages, C., J. Witting, E. Tambutte and K.P. Sebens: Effect of natural zooplankton feeding on the tissue and skeletal growth of the scleractinian coral Stylophora pistillata. Coral Reefs, 22, 229$240(2003)$

Finelli, C.M., B.S.T. Helmuth, N.D. Pentchefand D.S. Wethey: Intracolony variability In photosynthesis by corals is affected by water flow: Role of oxygen flux. Mar. Ecol. Prog. Ser., 349, 103-110 (2007).

Finelli, C.M., B.S.T. Helmuth, N.D. Pentchef and D.S. Wethey: Water flow influences oxygen transport and photosynthetic efficiency in corals. Coral Reefs, 25, 47-57 (2006).

Goh, A.H. and A. Sasekumar: The community structure of the fringing coral reef, Cape Rachado, Malaya. J. Atoll Res. Bull., 24, 1-11 (1981).

Hii, Y.S., C.L. Soo and H.C. Liew: Feeding of scleractinian coral, Galaxea fascicularis, on Artemia salina Nauplii in captivity. J. Aquacul. Inter., 17, 363-376 (2009).

Karpenko, D. and V. Ganapetyan: Light in the Reef Aquaria. Retrieved from: https://www.advancedaquarist.com/ 2012/10/aafeature (2017. June 25).

Lee, Y.L., M.I.H. Mohamed, B.J. Sidik and J.H. Ali: Ecology of scleractinian corals in the waters of Port Dickson and their tolerance to sedimentation. The $4^{\text {th }}$ Annual Seminar of National Science Fellowship 2004, pp. 597-602 (2004).

Lim, C.Y.: Under The Murky Sea, Tanjung Tuan's Coral Reefs Are Being 
Wiped Out. Retrieved from http://www.thestar.com.my/lifestyle/ features/2015/04/20/tanjung-tuan-coral-reefs-struggle-tosurvive/ 2015, April 20.

Philipp, E. and K. Fabricius: Photophysiological stress in scleractinian corals in response to short-term sedimentation. J. Exp. Mar. Biol. Ecol., 287, 57-78 (2003).

Rocha, R., R. Calado, P. Cartaxana, J. Furtado and J. Serôdio: Photobiology and growth of leather coral Sarcophyton cf. glaucum fragments stocked under low light in a recirculated system. Aquaculture, 414-415, 235-242 (2013).

Rodolfo-Metalpa, R., A. Peirano, F. Houlbreque, M. Abbate and F. Page: Effects of temperature, light and heterotrophy on the growth rate and budding of the temperate coral Cladocora caespitosa. Coral Reefs, 27, 17-25 (2007).

Rogers, C.: The effect of shading on coral reef structure and function. $J$. Exp. Mar. Biol. Ecol., 41, 269-288 (1979).

Schutter, M., S. Kranenbarg, R.H. Wijfels, J.A.J. Verreth and R. Osinga: Modification of light utilization for skeletal growth by water flow in the scleractinian coral Galaxea fascicularis. Mar. Biol., 158, 769$777(2011)$
Tamir, C., B. Ami and P. Zohar: Morphological variation in the oral disc of the Scleractinian coral Favia speciosa (Dana) at Indonesia. J. Comput. Biol. Chem., 32, 345-348 (2008).

Tentori, E. and D. Allemand: Light-enhanced calcification and dark decalcification in isolates of the soft coral Cladiella $\mathrm{sp}$. during tissue recovery. Biol. Bull., 211, 193-202 (2006).

Thimijan, R.W. and R.D. Heins: Photometric, radiometric and quantum light units of measure: A review of procedures for interconversion. HortScience, 18, 818-822 (1982).

Van, O.N., L. Masse, G.M. Sere, R.S. Joseph, D. Schoeman and A. Smit: Influence of heterotrophic feeding on the survival and tissue growth rates of Galaxea fascicularis (Octocorralia: Occulinidae) in aquaria. Aquaculture, 330, 156-161 (2011).

Wijgerde, T., P. Schots, E.V. Onselen, M. Janse, E. Karruppannan, J.A.J. Verreth and R. Osinga: Epizoic acoelomorph flatworms impair zooplankton feeding by the scleractinian coral Galaxea fascicularis. Biol. Open, 2, 10-17 (2013).

Zar. J.H.: Biostatistical Analysis. $56^{\text {th }}$ Edition. Northern Illinois University, DeKalb (2010). 